\title{
Octapeptide Polymorphism Analysis of Slovak Autochtonous Cattle Breeds
}

\author{
L. TKÁČIKOVÁ ${ }^{1}$, R. VORÁLEK ${ }^{1}$, P. FILIPČIK ${ }^{2}$, I. MIKULA Sr. $^{1}$ \\ ${ }^{1}$ Institute of microbiology and immunology, University of Veterinary Medicine, Košice, Slovakia \\ ${ }^{2}$ Neuroimmunological institute, Slovak Academy of Sciences, Bratislava, Slovakia \\ Members of Center of Excellence for Alzheimer Disease and Neurodegenerative Diseases
}

Received August 15, 2005

Accepted September 5, 2006

\begin{abstract}
Tkáčiková L., R. Vorálek, P. Filipčik, I. Mikula Sr.: Octapeptide Polymorphism Analysis of Slovak Autochtonous Cattle Breeds. Acta Vet Brno 2007, 76: 47-50.

Octapeptide repeats are 24 bp long repeat segments in the PrP gene that may be present in different species in a different number of repetitions. The aim of the present study was to determine the prevalence of this polymorphism in the PrP gene of two Slovak autochtonous cattle breeds, namely Slovak spotted cattle $(n=89)$ and Slovak Pinzgau $(n=195)$. In the study's cohort of animals, repletion numbers 6 and 5 were found for the octapeptide repeats. We found 6/6 homozygous animals to be most prevalent $(96.1 \%)$; the remaining animals were $5 / 6$ heterozygous $(3.9 \%)$. We did not observe any 5/5 homozygous animals in the studied group. This analysis included only a small group of animals. However, the results suggest that animals with six octapeptide repeats are dominant in these Slovak cattle breeds.
\end{abstract}

PrP, octapeptide repeats, polymorphism, Slovak spotted cattle, Slovak Pinzgau

Prion protein $\left(\mathrm{PrP}^{\mathrm{C}}\right)$ is a glycoprotein expressed by most tissues and is attached to the cell membrane by a glycosyl-phosphatidylinositol anchor. NMR studies revealed that the prion protein has a globular domain and a long amino-terminal tail that contains repeated octapeptide domains that bind metal ions with high affinities (Hornshaw et al. 1995; Brown et al. 1997; Pauly et al. 1998; Burns et al. 2002). These octapeptide domains usually contain either five or six copies of a short, glycine-rich peptide-repeat that encodes for octapeptide Pro-His-Gly-Gly-Gly-Trp-Gly-Gln or its longer variants Pro-Gln/His-GlyGly-Gly-Gly-Trp-Gly-Gln (Goldmann et al. 1991).

In cattle, three PrP isoforms are known, arising from variation in the octapeptide repeat units, ranging from five to seven copies (Neibergs et al. 1992; Hunter et al. 1994; Schläpfer et al. 1998; Le one et al. 2002; Walaw ski et al. 2003). Previous studies showed no association between polymorphisms in the number of octapeptide repeats and bovine spongiform encephalopathy (BSE) susceptibility (Neibergs et al. 1992; Hunter et al. 1994). The first experimental confirmation that an increased number of octapeptide repetitions in the PrP gene may affect the susceptibility to experimental infection with BSE agents is in the study of Castilla et al. (2004, 2005). These authors reported that transgenic mice (boTg) carrying one or four extra octapeptide repeats in the bovine PrP gene ( 7 or 10 instead of 6 ) showed an altered course of BSE infection, reflected in reduced incubation times when compared with boTg mice expressing similar levels of the wild-type six-octapeptide protein.

Variations in the number of octapeptide repeat units were also observed in other species. In the human PrP gene 5 octapeptide repetitions are present and mutations resulting in variations of their number are often associated with the inherited prion disease (Goldfarb et al. 1991; Diedrich et al. 1992; Brown 1994; Croes et al. 2004).

In the goat PrP gene presence of 3 or 5 octapeptide repetitions has been detected (Goldmann et al. 1998; Billin is et al. 2002). The shorter allelic variant, containing only three instead of the usual five-octapeptide repeats, was supposed to be associated with an

Address for correspondence:

L. Tkáčiková

Institute of Microbiology and Immunology,

University of Veterinary Medicine, Komenského 73,

04181 Košice, Slovakia

E-mail: tkacikov@uvm.sk

http://www.vfu.cz/acta-vet/actavet.htm 
increased scrapie incubation period in goats (Goldmann et al. 1998). In the sheep PrP gene 5 copies of the octapeptide repeat are present (Goldmann et al. 1998).

The aim of the present study was to determine the number of octapeptide repeat in the PrP gene of Slovak autochthonous cattle breeds.

\section{Materials and Methods}

Samples from healthy cattle of two Slovak autochthonous breeds, the Slovak spotted cattle $(\mathrm{n}=89)$ and Slovak Pinzgau $(n=195)$ were included in the study. Genomic DNA was isolated from blood leukocytes (Sa mbrook et al. 1989). Amplification of octapeptide repeats including a part of the PrP gene was achieved by PCR amplification using primer pairs F: 5'-ACG TGG GCC TCT GCA AGA AGC GAC-3' and R: 5'-GCA CTT CCC AGC ATG TAG CCA CCA-3' (Walaw ski and Czarnik 2003) with an initial denaturation step at $94{ }^{\circ} \mathrm{C}$ for 5 min followed by 35 cycles of one-minute incubations at 95,65 and $72{ }^{\circ} \mathrm{C}$ with final extension $72{ }^{\circ} \mathrm{C}$ for 10 min. PCR products were analyzed on $1.8 \%$ ethidium-bromide-stained agarose gel.

\section{Results and Discussion}

We detected 5 octapeptide repeats $(349 \mathrm{bp}$ ) or 6 octapeptide repeats (373 bp) (Plate I, Fig. 1) in the studied cattle population. The frequency of 6/6-homozygote animals was higher in the Slovak spotted cattle $(97.7 \%)$ than in the Slovak Pinzgau $(95.4 \%)$. Consequently, the frequency of 6/5-heterozygous cattle was higher in the Slovak Pinzgau $(4.6 \%)$ than in the Slovak spotted cattle $(2.3 \%)$. Animals homozygous for 5 octapeptide repeats were not recorded in this group (Table 1). Similar distribution of octapeptide repeats was observed previously, where in the cohort of the Holstein-Friesian or Simmental breeds 6 octapeptide repeats were predominant, showing either $6 / 6$ homozygotes or $6 / 5$ heterozygotes, while homozygotes $5 / 5$ were not observed (Brown et al. 1993; McKenzie et al. 1992; Neibergs et al. 1992; Premzl et al. 2000; Leone et al. 2002). On the other hand, Walawski et al. (2003) and Walawski and Czarnik (2003) recorded a relatively high frequency of 6/5 heterozygous animals as well as some $5 / 5$ homozygous animals in the Polish Black and White cattle, which is improved by Holstein-Friesian crossing. These results indicate possibility of relation between octapeptide polymorphism and breed.

Table 1. Octapeptide allele distribution in Slovak spotted cattle and Slovak Pinzgau breeds

\begin{tabular}{|l|c|c|c|c|}
\hline & $\mathrm{n}$ & $6 / 6$ & $6 / 5$ & $5 / 5$ \\
\hline Slovak spotted cattle & 89 & $87(97.7 \%)$ & $2(2.3 \%)$ & 0 \\
\hline Slovak Pinzgau & 195 & $186(95.4 \%)$ & $9(4.6 \%)$ & 0 \\
\hline Total & 284 & $273(96.1 \%)$ & $11(3.9 \%)$ & $0(0 \%)$ \\
\hline
\end{tabular}

\section{Analýza polymorfizmu oktapeptidových repetícií u slovenských autochtónnych plemien hovädzieho dobytka}

Oktapeptidové repetície sú 24 bp dlhé opakujúce sa segmenty v PrP géne, ktoré sa môžu u rôznych druhov opakovane vyskytovat v rôznom počte repetícií. Cielom tejto práce bolo stanovit výskyt tohto polymorfizmu v PrP géne dvoch slovenských autochtónnych plemien - Slovenský strakatý $(n=89)$ a Pinzgauský dobytok $(n=195)$. Vo vyšetrovanej skupine zvierat boli zaznamenané dve variácie v počte oktapeptidových repetícií pozostávajúce z prítomnosti 5 alebo 6 repetícií. Zistili sme vysokú prevalenciu zvierat homozygótnych pre 6/6 oktapeptidových repetícií $(96.1 \%$ ) a nízku prevalenciu 6/5 heterozygótnych zvierat (3.9\%). V sledovanom súbore zvierat neboli nájdené žiadne zvieratá homozygótne pre 5/5 oktapeptidových repetícií. Toto štúdium zahrnulo iba malú skupinu zvierat, avšak 
dosiahnuté výsledky poukazujú na to, že šesti oktapeptidových repetícií má dominantné zastúpenie u týchto slovenských plemien dobytka.

\section{Acknowledgements}

This research was supported by Slovak Grant Agency VEGA 1/2328/05.

\section{References}

BILLINIS C, PANAGIOTIDIS CH, PSYCHAS V, ARGYROUDIS S, NICOLAOU A, LEONTIDES S, PAPADOPOULOS O, SKLAVIADIS T 2002: Prion protein gene polymorphism in natural goat Scrapie. J Gen Virol 83: 713-721

BROWN DR, ZHAN HM, DENIEESE SK, AX RJ 1993: Bovine prion gene allele frequencies determined by AMFLP and RFLP analysis. Anim Biotechnol 4: 47-57

BROWN DR 1994: Transmissible human spongiform encephalopathy (infectious cerebral amyloidois): Creutzfeldt-Jakob disease, Gerstmann-Straussler-Sheinker syndrome, and Kuru. Neurodegenerative disease, pp. 839-876.

BROWN DR, QUIN K, HERMS JW, MADLUNG A, MANSON J, STROME R, FRASER PE, KRUCK T, VON BOHLEN A, SCHULTZ-SCHAEFFER W, GIESE A, WESTAWAY D, KRETZSCHMAR HA 1997: The cellular prion protein bind copper in vivo. Nature 390: 684-687

BURNS CS, ARONOFF-SPENCER E, DUNHAM CM, LARIO P, AVDIEVICH NI, ANTHOLINE WE, OLMSTEAD MM, VRIELINK A, GERFEN GJ, PEISACH J, SCOTT WG, MILLHAUSER GL 2002: Molecular features of the copper binding sites in the octarepeat domain of the prion protein. Biochemistry 41: 3991-4001

CASTILLA J, GUTIERREZ-ADAN A, BRUN A, PINTADO B, PARRA B, RAMIREZ MA, SALGUERO FJ, DIAZ SAN SEGUNDO F, RABANO A, CANO MJ, TORRES JM 2004: Different behavior toward bovine spongiform encephalopathy infection of bovine prion protein transgenic mice with one extra repeat octapeptide insert mutation. J Neurosci 24: 2156-2164

CASTILLA J, GUTIERREZ-ADAN A, BRUN A, PINTADO B, SALGUERO FJ, PARRA B, SEGUNDO FD, RAMIREZ MA, RABANO A, CANO MJ, TORRES JM 2005: Transgenic mice expressing bovine PrP with a four extra repeat octapeptide insert mutation show a spontaneous, non-transmissible, neurodegenerative disease and an expedited course of BSE infection. FEBS Lett 579: 6237-6246

CROES EA, THEUNS J, HOUWING-DUISTERMAAT JJ, DERMAUT B, SLEEGERS K, ROKS G, VAN DEN BROECK M, VAN HARTEN B, VAN SWIETEN JC, CRUTS M, VAN BROECKHOVEN C, VAN DUIJN CM 2004: Octapeptide repeat insertions in the prion protein gene and early onset dementia. J Neurol Neurosurg Psychiat 75: 1166-1170

DIEDRICH JF, KNOPMAN DS, LIST JF, OLSON K, FREY WH II, EMORY CR, SUNG JH, HAASE AT 1992: Deletion in the prion protein gene in a demented patient. Hum Mol Genet 1: 443-444

GOLDFARB LG, BROWN P, MCCOMBIE WR, GOLDGABER D, SWERGOLD GD, WILLS PR, CERVENAKOVA L, BARON H, GIBBS CJ JR, GAJDUSEK DC 1991: Transmissible familial CreutzfeldtJakob disease associated with five, seven, and eight extra octapeptide coding repeats in the PRNP gene. Proc Nat Acad Sci U S A 88:10926-10930

GOLDMANN W, HUNTER N, MARTIN T, DAWSON M, HOPE J 1991: Different forms of the bovine PrP gene have five or six copies of a short, G-C-rich element within the protein- coding exon. J Gen Virol 72: 201-204

GOLDMANN W, CHONG A, FOSTER J, HOPE J, HUNTER N 1998: The shortest known prion protein gene allele occurs in goats, has only three octapeptide repeats and is non-pathogenic. J Gen Virol 79: 3173-3176

HORNSHAW MP, MCDERMOTT JR, CANDY JM, 1995: Copper binding to the N-terminal tandem repeat regions of mammalian and avian prion protein. Biochem Biophys Res Commun 207: 621-629

HUNTER N, GOLDMANN W, SMITH G, HOPE J, 1994: Frequencies of PrP gene variants in healthy cattle and cattle with BSE in Scotland. Vet Rec 135: 400-403

LEONE P, CASTIGLIONI B, SEHI T, CASSANI P, STELLA A 2002: Prion protein octarepeat variability in the Italian cattle breeds. Proc. $7^{\text {th }}$ World Congress on Genetic Applied in Livestock Production, August 19 - 21 , 2002, Montpellier, France, Communication No 13-40

MCKENZIE DI, COWAN CM, MARSH RF, AIKEN JM 1992: PRP gene variability in the US cattle population. Anim Biotechnol 32: 309-315

NEIBERGS HL, RYAN AM, WOMACK JE, SPOONER RL, WILLIAMS JL 1992: Polymorphism analysis of the prion gene in BSE-affected and unaffected cattle. Anim Genet 25: 313-317

PAULY PC, HARRIS DA 1998: Copper stimulates endocytosis of the prion protein. J Biol Chem 273(50): 33107-33110

PREMZL M, BOZIC P, GAMULIN V 2000: PRNP octarepeat allele genotype frequencies among the modern and rare cattle breeds in Croatia. Anim Genet 31: 408-409

SAMBROOK J, FTISISCH EF, MANIATIS T 1982: Molecular Cloning: A Laboratoral Manual. Cold Spring Harbor Laboratory Press, Cold Spring Harbor, NY. 
SCHLÄPFER J, SAITBEKOVA N, GAILLARD C, DOLF G 1998: A new allelic variant in the bovine prion protein gene (PRNP) coding region. Anim Genet 30: 386-387

WALAWSKI K, CZARNIK U, WOJCIECHOWSKI R, PAREEK CS 2003: Abnormal segregation of prion protein octapeptide-repeat alleles in cattle. J Appl Genet 44: 375-378

WALAWSKI K, CZARNIK U 2003: Prion octapeptide-repeat polymorphism in Polish Black-and-White cattle. J Appl Genet 44: 191-195 
Tkáčiková L. et al.: Octapeptide Polymorphism ... pp. 47-50

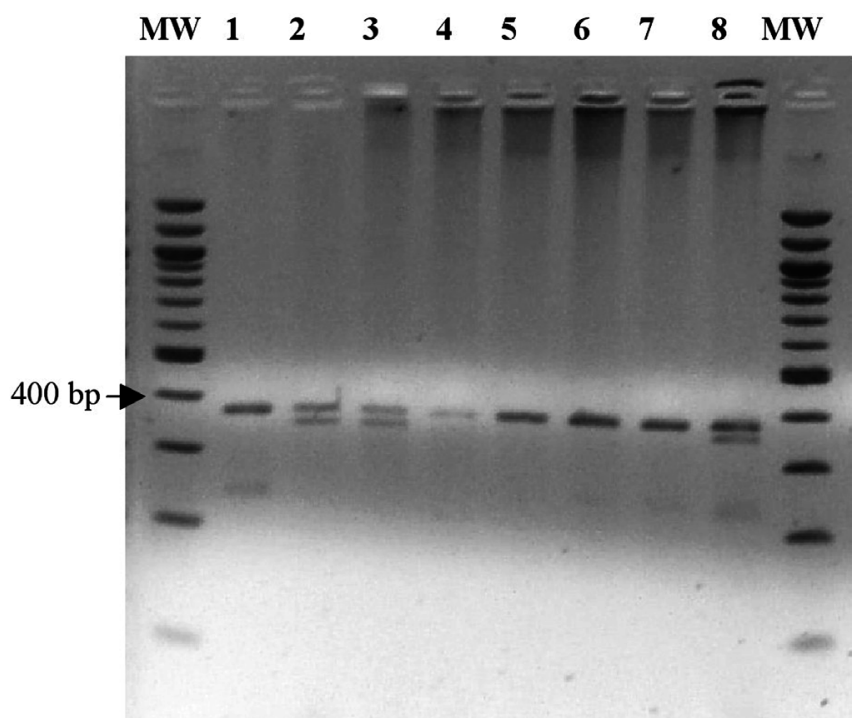

Fig. 1. Ethidium bromide stained PrP fragments amplified from a 6/6 homozygous cattle (lanes 1 , $4,5,6,7$ ) and from $6 / 5$ heterozygous cattle (lanes $2,3,8$ )

Standard of molecular weight - 100 bp DNA ladders 